\title{
A Simple Kit of Plate-Trapped Antigen Enzyme-Linked Immunosorbent Assay for Identification of Plant Viruses ${ }^{1}$
}

\author{
Um Simples Kit de "Enzyme-Linked Immunosorbent Assay" para Identificação de \\ Vírus de Planta
}

\author{
Aline Kelly Queiróz Nascimento ${ }^{2}$, José Albersio Araújo Lima ${ }^{2 *}$ and Graziela da Silva Barbosa ${ }^{2}$
}

\begin{abstract}
Many methods can be used for arriving in a correct virus disease diagnose, and the serological techniques are the most used methods for plant virus identification. The indirect enzyme-linked immunosorbent assay (Indirect-ELISA) or plate-trapped antigen ELISA (PTA-ELISA) has been useful for detection of viruses in a wide range of situations, especially to test a large number of samples in a relatively short period of time. Immune-biological Companies have developed practical kits for direct ELISA or double antibody sandwich (DAS-ELISA), but neither Company has developed kits for PTA-ELISA. As a single universal antibody-conjugate is used for detection of a wide range of plant viruses, the PTA-ELISA technique is more economical, practical and suitable for virus detection. Considering also the great problem of including infectious plant viruses in DAS-ELISA kits, a simple kit for PTA-ELISA was developed for plant virus identification. Extracts from infected plant tissues were added into the ELISA plate wells, which were sealed with plastics and maintained in the refrigerator and Laboratory conditions for different periods of time. The plates were tested by the regular PTA-ELISA and after 20 months of incubation, the plate showed excellent results when used for detection of six virus species from the genera Comovirus, Cucumovirus, Potyvirus and Sobemovirus in infected plant tissues. The ELISA plate trapped virus together with its specific antiserum could constitute a simple kit, which will permit the exchange of antisera among virologists without transferring infectious viruses from one laboratory to another to be used as control.
\end{abstract}

Key words: Plant Virus Diagnose. ELISA. Comovirus. Cucumovirus. Potyvirus. Sobemovirus.

\begin{abstract}
RESUMO - Muitos métodos podem ser utilizados para uma correta diagnose de doenças ocasionadas por vírus, e os métodos sorológicos são os mais utilizados. O teste de ELISA "enzyme-linked immunosorbent assay" indireto ou placa tratada com antígeno (PTA-ELISA) é realizado para detecção de vírus em várias situações, especialmente para testes de elevado número de amostras em curto período de tempo. Empresas que comercializam imunobiológicos têm desenvolvido kits práticos de ELISA direto ou ELISA sanduíche duplo (DAS-ELISA), mas nenhuma delas desenvolveu kits de ELISA indireto ou PTAELISA. Como um anticorpo universal conjugado a uma enzima é usado na técnica de PTA-ELISA para detecção de vasta gama de vírus, PTA-ELISA é a técnica mais econômica, prática e adequada. Considerando também o problema da inclusão de vírus como controle positivo em kits comerciais de DAS-ELISA, um kit sorológico de PTA ELISA foi desenvolvido para identificação de vírus de planta. Extratos de tecidos infetados foram adicionados a poços de placas de ELISA, que após lavagem e secagem foram seladas com adesivo plástico e mantidas em refrigerador e em condições de laboratório por diferentes períodos. Após 20 meses de incubação, as placas do kit mostraram excelentes resultados na detecção de seis espécies de vírus dos gêneros Comovirus, Cucumovirus, Potyvirus e Sobemovirus. Placas de ELISA previamente tratadas com vírus, juntamente com antissoros específicos podem constituir um kit de PTA-ELISA, que proporcionará eficiente diagnose de viroses vegetais e permitirá permuta de antissoros entre grupos científicos sem a transferência de vírus infectivo de um laboratório para outro.
\end{abstract}

Palavras-chave: Diagnose de viroses de planta. ELISA. Comovirus. Cucumovirus. Potyvirus. Sobemovirus.

DOI: $10.5935 / 1806-6690.20170025$

*Autor para correspondência

${ }^{1}$ Recebido para publicação em 22/01/2014, aprovado em 12/04/2016

Parte da Tese de Doutorado da primeira autora apresentada no Programa de Pós-Graduação em Agronomia/Fitotecnia/CCA/UFC, financiada pelo CNPq e funcap

${ }^{2}$ Laboratório de Virologia Vegetal, Departamento de Fitotecnia, Universidade Federal do Ceará/UFC, Av. Mister Hull, s/n, Campus do Pici, Bloco 805, Caixa Postal 6035, Fortaleza-CE, Brasil, 60.356-001, alynekellly@yahoo.com.br, albersio@ufc.br, grazzy26@bol.com.br 


\section{INTRODUCTION}

The diseases caused by virus are generally difficult to control and several of them cause serious problems for the crop productions. Virus infections generally results in plant decline and consequent reduction in the plants and orchards longevity, with reduction of quality and quantity of production. An adequate diagnosis procedure with a correct virus identification and determination of its distribution in the field are essential for establishing efficient control measures. For this reason, biological, serological and molecular methods have been developed for identification and detection of plant virus infections in the field. The serological techniques have been the most used methods for rapid and efficient detection of plant viruses in several plant samples, including in programs to produce virus free plant material (LIMA et al., 2012; NAIDU; HUGHES, 2003; SHIM et al., 2006; UEHARAICHIKI et al., 2013).

Many methods have been developed for the detection and identification of plant viruses and sometimes a combination of methods is needed for unequivocal diagnosis (NAIDU; HUGHES, 2003). The correct diagnose of a plant virus diseases can be accomplished by one or a combination of methods involving the morphological, physical, biological, cytological, serological and molecular properties of the viruses, but serology is one of the most specific and easy method to obtain a rapid and precise identification of plant viruses. The great value of the serological methods for virus identification is based on the specific reaction between the antigens and its specific antibody.

Among several serological methods developed and used successfully for plant virus identification the enzymelinked immunosorbent assay (ELISA) has been very useful and popular since it was introduced to plant virology by Clark and Adams (1977). ELISA is used in a wide range of situations, especially to test a large number of samples in a relatively short period of time. Many variations of ELISA have been developed, which fall into two broad categories: "direct" and "indirect" ELISA procedures (ALMEIDA; LIMA, 2001; COOPER; EDWARDS, 1986; LIMA et al., 2012). The direct ELISA also called double antibody sandwich (DAS) ELISA is highly strain-specific and requires each detecting antibody to be conjugated to an enzyme. The indirect ELISA requires antibodies produced in two different animal species and the virus particles are trapped in the wells of the ELISA plate. For this reason, this method is also known as plate-trapped antigen (PTA) ELISA (LIMA et al., 2012; WARD et al., 2004).

The PTA-ELISA has been useful for detection viruses in a wide range of situations, especially to test a large number of samples in a relatively short period of time. Immune-biological Companies have developed practical kits for DAS-ELISA, but neither Company has developed kits for PTA- ELISA (LIMA et al., 2012; LIMA; SITTOLIN; LIMA, 2005).

The PTA-ELISA requires a universal IgG enzyme conjugate composed of an IgG produced against the IgGs from the animal in which the virus antibodies are raised (ASTIER et al., 2007). As a single universal antibodyconjugate is used for detection of a wide range of plant viruses, the PTA-ELISA technique is more economical, practical and suitable for virus detection in disease diagnosis programs (BOONHAM et al., 2013).

Considering the great problem of including infectious plant viruses in DAS-ELISA kits, the objective of the present paper was to develop and validate a simple PTA-ELISA kit for plant virus identification.

\section{MATERIAL AND METHODS}

The viruses used in this study belong to the active bank of plant viruses from the Plant Virus Laboratory at the Federal University of Ceará (UFC), Fortaleza-CE, Brazil. ELISA plates trapped antigens were prepared with six virus species from the family Secoviridae, Comovirus genus (Squash mosaic virus, SQMV and Cowpea severe mosaic virus, CPSMV), family Bromoviridae, Cucumovirus genus (Cucumber mosaic virus, CMV), family Potyviridae, Potyvirus genus (Cowpea aphidborne mosaic virus, CABMV and Zucchini yellow mosaic virus, ZYMV) and Sobemovirus (Papaya lethal yellowing virus, PLYV) in infected plant tissues (NASCIMENTO et al., 2010; SILVEIRA et al., 2005). ELISA plate wells were also treated with extracts from healthy plants of cowpea [Vigna unguiculata (L.) Walp subsp. unguiculata], papaya (Carica papaya L.) and melon (Cucumis melo L.) to function as control.

Approximately $0.1 \mathrm{~g}$ of infected plant tissues were ground in $900 \mu \mathrm{l}$ of the extraction buffer $(0.15 \mathrm{M}$ $\mathrm{Na}_{2} \mathrm{CO}_{3}, 0.035 \mathrm{M}$ of $\mathrm{NaHCO}_{3}$ and $0.007 \mathrm{M}$ of sodium diethyldithiocarbamate, $\mathrm{pH}$ 9.6) and the obtained extracts were added into the ELISA plate wells and the plates were incubated at $37^{\circ} \mathrm{C}$ for $2 \mathrm{~h}$ or overnight at $4{ }^{\circ} \mathrm{C}$. After washing with Phosphate Buffer Saline - PBS (0.137 M $\mathrm{NaCl}, 0.027 \mathrm{M} \mathrm{KCl}, 0.091 \mathrm{M} \mathrm{NaH}_{2} \mathrm{PO}_{4} .2 \mathrm{H}_{2} \mathrm{O}, 0.018 \mathrm{M}$ $\left.\mathrm{KH}_{2} \mathrm{PO}_{4}, \mathrm{pH} 7,4\right)$ and drying, the plates were sealed with adhesive plastic and maintained in the refrigerator $\left(4^{\circ} \mathrm{C}\right)$ at Laboratory conditions $\left(25^{\circ} \mathrm{C}\right)$. The antigen trapped plates were tested at 30-days intervals by the regular PTA-ELISA method, following the steps $100 \mu \mathrm{L}$ of the polyclonal virus antisera produced in rabbits previously absorbed with extracts from healthy plants that were produced in the Plant Virus Laboratory at UFC, and diluted to 2,000 were added into the wells. The plates were incubated again at 
$37{ }^{\circ} \mathrm{C}$ for $1 \mathrm{~h}$, after which they were washed three times with PBS-Tween. After drying, $100 \mu \mathrm{L}$ of goat anti rabbit IgG conjugated to alkaline phophatase, diluted to $1: 2,000$ in a buffer containing $2 \%$ of polyvinylpyrrolidone, $0.2 \%$ albumin and $0.02 \%$ sodium azide was added into the wells. The plates were incubated once more at $37^{\circ} \mathrm{C}$ for $1 \mathrm{~h}$ and washed three times with PBS-Tween. Finally, $100 \mu \mathrm{L}$ of a substrate of p-nitrophenyl phosphate in the concentration of $0.5 \mathrm{mg} / \mathrm{mL}$ dissolved in a buffer containing $12 \%$ of diethanolamine and $0.25 \%$ of sodium azide, $\mathrm{pH} 9.8$ was added into the wells. After 20 and 40 min the plates were analyzed in the ELISA plate reader apparatus, using a filter of $405 \mathrm{~nm}$ wave lengths (CEZARE; SCHONS; LAU,
2011; FEGLA; KAWANNA, 2013; NASCIMENTO et al., 2010).

The ELISA plates treated with extracts from infected and health plants maintained in the refrigerator $\left(4{ }^{\circ} \mathrm{C}\right)$ and at Laboratory conditions $\left(25^{\circ} \mathrm{C}\right)$ were evaluated at each month for a period of 20 months.

\section{RESULTS AND DISCUSSION}

After 20 months of incubation, the plate trapped antigens showed excellent results when used for detection

Figure 1 - Absorption readings at 1, 10, 15 and 20 months after the ELISA plates were treated with extracts from healthy plants and plants infected with Squash mosaic virus (SQMV), Cowpea severe mosaic virus (CPSMV), Cucumber mosaic virus (CMV), Cowpea aphidborne mosaic virus (CABMV), Zucchini yellow mosaic virus (ZYMV) and Papaya lethal yellowing virus (PLYV). A) Plates maintained in the refrigerator and B) Plates maintained at laboratory conditions
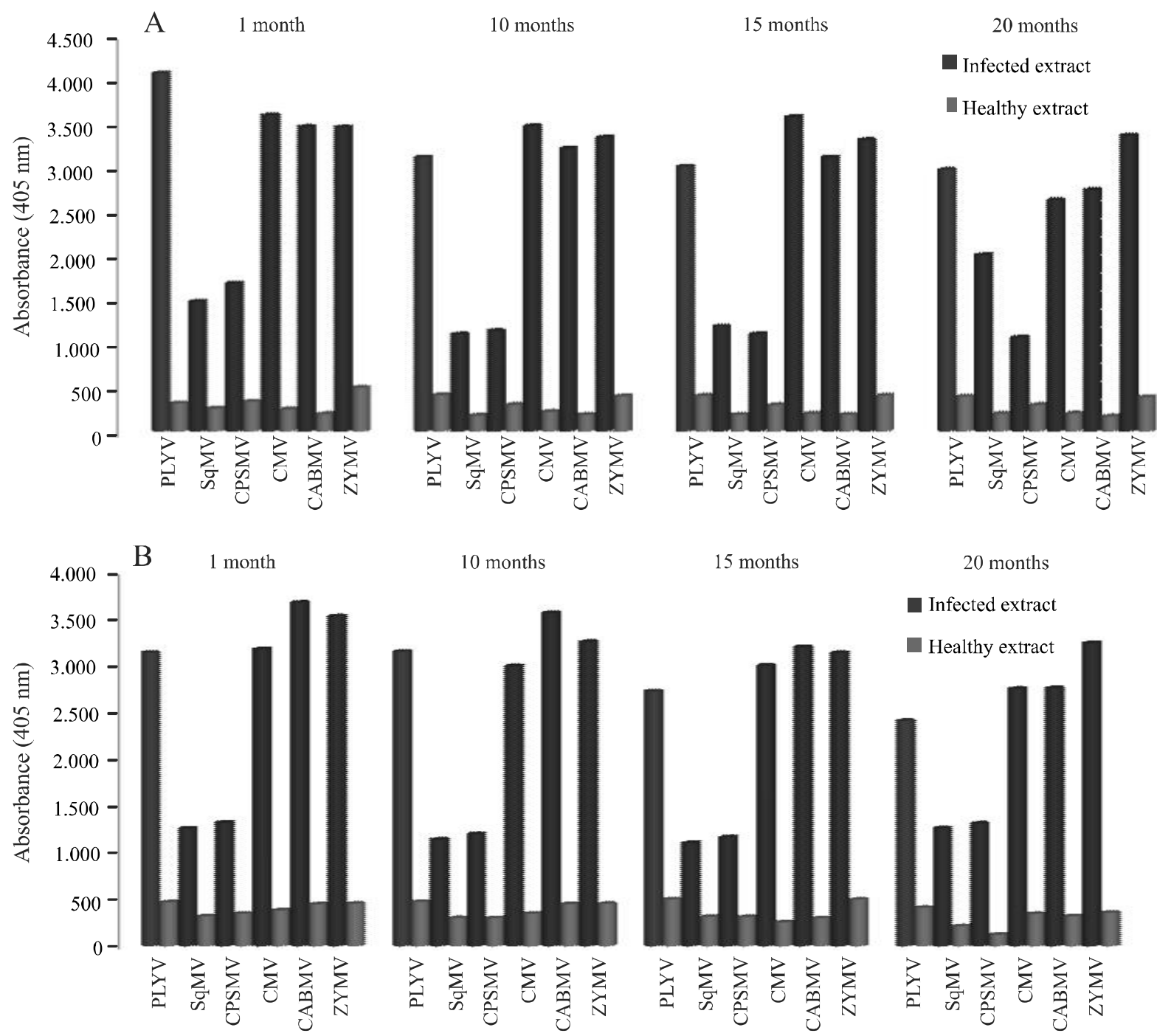

\section{0 months}

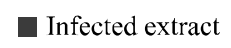

Healthy extract 
of all virus species evaluated from the Comovirus genus (SQMV and CPSMV), Cucumovirus (CMV), Potyvirus (CABMV and ZYMV) and Sobemovirus (PLYV) in infected plant tissues. The ELISA absorption reading values for all the ELISA plate wells previously treated individually with plant extracts infected with SQMV, CPSMV, CMV, CABMV, ZYMV and PLYV maintained in the refrigerator and at Laboratory conditions were over three times the values obtained for the respective controls with extracts of healthy plants (Figures 1A, B).

Adequate diagnosis procedures with correct virus identification are important for establishing appropriated plant disease control program (JAN et al., 2012; MILLER; BEED; HARMON, 2009; NASCIMENTO et al., 2011; NJUKENG et al., 2004; XIE et al., 2013). The plate trapped viruses together with their specific antisera could constitute a simple but unique and important PTAELISA kit, which will permit detection of several plant viruses in only one diagnostic kit. The virus diagnosis and identification kit will also permit the exchange of antisera among virologists without transferring infectious viruses from one laboratory to another to be used as control (Figure 2). If commercialized the PTA-ELISA kit could be used safely including for indexing virus which do not occur in a specific region, State or Country and reduce the Brazilian dependence to import plant virus diagnostic kit for virus identification and survey.

The plate incubation periods and the absorption values obtained with the PTA-ELISA demonstrated that the incubation time did not interfere with the kit efficiency

Figure 2 - Simple PTA-ELISA kit developed at the Plant Virus Laboratory from Federal University of Ceará, Brazil, composed of ELISA plate with holes treated with antigen for specific plant virus and extracts from healthy plant; virus specific antiserum, and buffers for antiserum dilution and preparation of plant samples

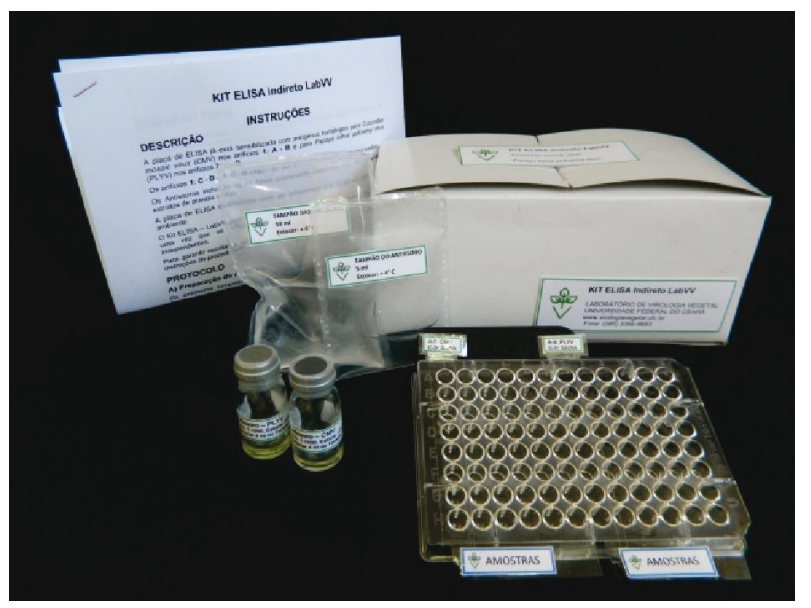

for plant virus identification. The analyzed data also demonstrated that the antigen sensitized plates could be stored in the refrigerator as well as in Laboratory conditions for up to 20 months without losing their efficiency and specificity. Commercial kits for DAS-ELISA have usually an expired period of six to 12 months.

The developed PTA-ELISA kit presented high sensitivity and showed very high specificity for detection of viruses that cause serious and economical losses in important Brazilian crops. Considering that the new developed PTA-ELISA kit could be used to detect simultaneously up to four different plant virus species in the same ELISA plate, instead of the use of kit for each virus like the commercial kits available by multinational companies. For this reason, the new developed PTAELISA kit could be considered a great technological advance for the Country and a technical support for the Brazilian scientific communities.

\section{CONCLUSIONS}

The simple PTA-ELISA kit developed in the present research showed the following advantages for identification of plant viruses:

1. As it is a PTA-ELISA technique it is economical, practical and suitable for virus detection of a wide range of plant viruses;

2. As the kit is composed of ELISA plates trapped with viruses, it will permit the exchange of antisera among virologists without transferring infectious viruses from one laboratory to another to be used as control;

3. The kit can be composed with several plant virus antigens and antisera to be used for identification of more than one virus from different species or genus, at the same time.

\section{REFERENCES}

ALMEIDA, A. M. R.; LIMA, J. A. A. Técnicas sorológicas aplicadas à fitovirologia. In: ALMEIDA, A. M. R; LIMA, J. A. A. Princípios e técnicas aplicados em fitovirologia. Fortaleza: Edições Sociedade Brasileira Fitopatologia, 2001. p. 33-62.

ASTIER, S. et al. Principles of plant virology: genome, pathogenicity, virus ecology. Hampshire, USA: Science Publishers, 2007. 500 p.

BOONHAM, N. et al. Methods in virus diagnostics: from ELISA to next generation sequencing. Virus Research, p. 1-12, 2014.

CEZARE, D. G. de; SCHONS, J.; LAU, D. Análise da resistência/tolerância da cultivar de trigo BRS Timbaúva ao Barley yellow dwarf virus - PAV. Tropical Plant Pathology, v. 36, n. 4, 2011. 
CLARK, M. F.; ADAMS, A. N. Characteristics of the microplate method of enzyme-linked immunosorbent assay for the detection of plant viruses. Journal General Virology, v. 34 , p. 475-483, 1977.

COOPER, J. I., EDWARDS, M. L. Variations and limitations of enzyme amplified immunoassays in developments and aplications in virus testing. Edited by R. A. C. Jones and L. Torrance. Wellesbourne, U. K.: Association of Applied Biologists, 1986. p. 139-154.

FEGLA, G.; KAWANNA, M. Improved indirect ELISA for detection of some plant viruses. International Journal of Agriculture \& Biology, v. 15, p. 939-944, 2013.

JAN, A. T. et al. Technical advancement in plant virus diagnosis - an appraisal. Archives of Phytopathology and Plant Protection, v. 45, p. 909-921, 2012.

LIMA, J. A. A.; SITTOLIN, I. M.; LIMA, R. C. A. Diagnose e estratégias de controle de doenças ocasionadas por vírus. In: FREIRE FILHO, F. R. et al. Feijão caupi: avanços tecnológicos. Brasília: Embrapa Informação Tecnológica, 2005. p. 404-459.

LIMA, J. A. et al. Serology applied to plant virology. In: MOSLIH AL-MOSLIH (Ed.). Serological diagnosis of certain human, animal and plant diseases. Rijeka: In Tech, 2012. p. 70-94.

MILLER, S. A.; BEED, F. D; HARMON, C. L. Plant disease diagnostic capabilities and networks. Annual Review of Phytopathology, v. 47, p. 15-38, 2009.

NAIDU, R. A.; HUGHES, J. D. A. Methods for the detection of plant viral diseases in plant virology in Sub-Saharan Africa. In:
HUGHES, J. D.A., ODU B (Ed.). Proceeding of plant virology. Ibadan, Nigeria: I.I.T.A, 2003. p. 233-260.

NASCIMENTO, A. K. Q. et al. Biological, physical, and molecular properties of a Papaya lethal yellowing virus isolate. Plant Disease, v. 94, p. 1206-1212, 2010.

NASCIMENTO, A. K. Q. et al. Indirect enzyme linked immunosorbent assay and polymerase chain reaction for detection of viruses in banana tissues. In: CONGRESSO BRASILEIRO DE FITOPATOLOGIA, 44., 2011, Bento Gonçalves. Resumos... Bento Gonçalves: Tropical Plant Pathology, 2011. p. 612.

NJUKENG A. P. et al. Development of serological procedures for rapid, sensitive and reliable detection of Yam mosaic virus genus Potyvirus in yam tissues. Tropical Science, v. 44, p. 136-147, 2004.

SHIM, C. K. et al. Construction of antibodies for detection and diagnosis of Cucumber green mottle mosaic virus from watermelon plants. Plant Pathology Journal, v. 22, p. 21-27, 2006.

SILVEIRA, L. M. et al. Seleção de acessos e progênies de Citrullus spp. para resistência a três potyvírus. Fitopatologia Brasileira, v. 30, p. 394-399, 2005.

UEHARA-ICHIKI, T. et al. Detection and diagnosis of riceinfecting viruses. Frontiers in Microbiology, v. 4, p.1-7, 2013.

WARD, E. et al. Plant pathogen diagnostics: immunological and nucleic acid-based approaches. Annals of Applied Biology, v. 145, p. 1-16, 2004.

XIE Y. et al. Highly sensitive serological methods for detecting tomato yellow leaf curl virus in tomato plants and whiteflies. Virology Journal, v. 10, p. 142, 2013. 